\begin{tabular}{c} 
Volume and Issues Obtainable at Center for Sustainability Research and Consultancy \\
Journal of Accounting and Finance in Emerging Economies \\
ISSN: 2519-0318 ISSN (E) 2518-8488 \\
Volume 5: Issue 2 December 2019 \\
CSRᄃ \\
Journal homepage: www.publishing.globalcsrc.org/jafee \\
\hline
\end{tabular}

\title{
The Effects of Independent Audit Committee on the Accounting Policy Decisions of Nigerian Firms
}

\author{
${ }^{1}$ Muhammad Aminu Isa
}

${ }^{1}$ Department of Accounting, Bayero University Kano, Nigeria, maisa.acc@buk.edu.ng

\begin{tabular}{ll}
\hline \multicolumn{1}{c}{ ARTICLE DETAILS } & ABSTRACT \\
\hline History & Purpose: The study examines the effects of the independent audit \\
Revised format: November 2019 & $\begin{array}{l}\text { committee on the accounting policy decisions of firms. Managers use their } \\
\text { discretion in accounting decisions against the interests of shareholders. } \\
\text { Independent audit committees are relied upon by the shareholders for } \\
\text { monitoring. }\end{array}$ \\
\hline Keywords & Design/Methodology/Approach: Data were generated from the financial \\
Accounting Policy, Decisions, & reports of the sampled firms and a model similar to Bowen DuCharme and \\
Audit Committee Independence & Shores (1995) and Jackson, Xiaotao and Cecchini (2009) was used to \\
& estimate the predictive capacity of the independent audit committee in the \\
process. & Findings: It was found that the firms predominantly decided on income \\
increasing policies but did not find any significant evidence that & independent audit committee monitoring is effective on accounting \\
decisions. & Implications/Originality/Value: The firms set up audit committees not \\
because they rely on them for effective monitoring but to fulfil statutory \\
requirements of CAMA 2014, as amended. This conclusion is consistent \\
with the view of Menon and Williams (1994). This evidence extends the \\
literature of accounting choice in relation to the role of audit process.
\end{tabular}

(C) 2019 The authors, under a Creative Commons Attribution-Non

Commercial 4.0

Corresponding author's email address:

Recommended citation: Isa, M. A., (2019). The Effects of Independent Audit Committee on the Accounting Policy Decisions of Nigerian Firms. Journal of Accounting and Finance in Emerging Economies, 5 (2), 203-214

DOI: $10.26710 /$ jafee.v5i2.825

\section{Introduction}

From the perspective of the agency theory, managers could be opportunistic by choosing accounting policies using their discretion to manipulate accounting income to optimize their benefits (Healy, 1985). Section 359: 3-4 of CAMA (2004) requires firms to establish an audit committee to safeguard the corporate accounting decision process to protect the interests of shareholders. The committee became a listing requirement in 1990 (CAMA, 2004) and the SEC code of 2011 institutionalized its independence with independent directors to foster effective monitoring. The independence of the audit committee came under attack for inadequate oversight in recent years in Nigeria (Chukwunedu, Ogochukwu and Chiedu, 2015). An independent audit committee is required to effectively protect the interests of shareholders from the managers. According to Carcello and Neal (2003) and Poretti, Schatt and Bruynseels (2018), the effectiveness of the audit committee depends majorly on its independence.The composition of the committee assumes a critical role assessing the quality of its monitoring of the accounting policy 
decision process. The code of corporate governance requires that independent directors should compose half of the committee membership (SEC, 2011). It is hypothesized in this study that higher proportions of the independent directors in the committeewouldsupport effective monitoring of theaccounting policy decisions of the firms to ensure that the incentives behind the selections of the methods are in the interest of the shareholders.

The audit committee started as a part of corporate governance mechanism in the US in the late 1930s (Bealing, Nelson and Staley, 2006) and became a listing requirement in 1972 (Fitchtner, 2010). The Sarbanes-Oxley Act bolstered itsinstitutionalization (Naciri, 2008). However, Menon and Williams (1994) observed that most firms do not rely on the committee to stimulate the eminence of the financial reporting process. Accounting policy choice is a discretion in the reporting permitted within GAAP (Bagnoli and Watts, 2005).Top management deploy this latitude to reduce the constraints imposed by their agency contracts in particular where managerial compensations are tied to reported income (Warfield, Wild and Wild, 1995). However, wherethe incentives of managerscoincide with the owners'then accounting policy decisions would create information asymmetry and influence stock returns (Dhaliwal, Salamon and Smith, 1982; Fields, Lys, and Vincent, 2001). The need to meet up withand protect the interests of the firm's stakeholders serves as a singificant incentive to accounting policy decisions (Ndjetcheu, 2012). Managers used their discretion in accounting policy decisions to managethe expectations of stakeholders with implicit claims (Bowen DuCharme and Shores (1995).A bonus plan compensation scheme is not popular among Nigerian listed firms.Therefore, managers' incentives for accounting choice would be for other purposes, such as managerial reputation and job security rather than financial compensation. Still, managers could be opportunistic in their choice of the accounting method because the impact is commensurate with that of the bonus plan.

The discretionof managers in accounting choice usually could be in the decisions to use either fair-value or cost methodin reporting economics events of firms (Cairns et al. 2011). These measurements have different effects on the reported income and the prediction of the firm's future operating cash flows (Holthausen, 1990; Healy and Wahlen, 1999; Beneish, 2001). Some of these latitudes are found in International Accounting Standards (IAS)2, 16,38 and 40 forthe measurementsof inventory, property, plant and equipment, intangible assets and investment property respectively. Nigerian firms started using international standards to prepare financial statements since 2010 and managers utilize this discretion for opportunistic purposes. Independent audit committeesare considered the ultimate mechanisms to ensure that managers are better monitored on this discretion (Klein, 2002; DeZoort, et al., 2002). Accounting policy decisions need to be closely monitored as they have similar objectives as the earnings management (Dhaliwal, Salamon and Smith, 1982; Fields, Lysand Vincent, 2001). However, the independence of the audit committee in Nigeria does not support effective monitoring on firms' accounting process (Moses,2016; Oliver and Grace, 2017) and the management of the firms could use their discretion against the interest of the shareholders.

Fields, Lysand Vincent (2001) noted that studies (such as Dhaliwal, Salamon and Smith, 1982; Bowen DuCharme and Shores, 1995; Astami and Tower, 2006; Dey, Grinyerand Sinclair, 2008; Waweru, Ntui and Mangena, 2011; Isa, 2014) did not include the influence of the auditing process on accounting policy decisions. This has left out an important variable in the literature of accounting choice. According to Parker (1997) and Abbott and Parker (2000), there is growing evidence that the independence of an audit committee is vital to mitigating the adverse consequences of managers' discretions and the manipulations of the accounting process. The objectives of the study are, first, to examine the nature of accounting policy decisions of the firms and, second, to examine the effects of an independent audit committee on a firm's accounting policy decisions to provide the basis for assessing the relevant corporate governance code that affects audit committee independence. To the best of the knowledge of the researcher, the predictive capacity of the audit committee's independence on accounting policy decisions is yet to be addressed in any study. The next part of the paper presents the literature review, part three reports the research design, part four presents the results and discussions and, lastly, part five reports the summary and conclusions.

\section{Literature Review}

\subsection{Accounting Policy Decisions}

Accounting policy decisions would have income-increasing or income-decreasing effects on the firm's reported income permissive within the prescribed methods that lead to inefficient contracting (Bowen DuCharme and Shores, 1995; Watts and Zimmerman, 1978; Fields, Lys and Vincent, 2001; Francis, 2001). According to Isa (2014), Nigerian firms used accounting policies that increase their reported income. 
The incentive to choice income increasing methods is then derived by the need to: increase managerial compensation, particularly when tied to reported income, avoid firms' violating debt covenants and reduce their political costs (Watts and Zimmerman, 1978 and 1990). The bonus-plan and debt violation explanations do not apply to the Nigerian business environment. Ndjetcheu (2012) argued that firms in the Sub-Saharan Africa select accounting policies that reduce the tax burden, consistent with Zmijewski and Hagerman (1981). There are other implicit incentive obligations to the firms that could apply to Nigeria discovered to be associated with accounting policy decisions (Bowen DuCharme and Shores, 1995; Jackson, Xiaotao and Cecchini, 2009). These include labour intensity in organizations and continuous patronage of short-term creditors and the suppliers of inputs. The concentration of ownership and owner-control boards also predicts the decisions on which accounting policy to adopt by firms (Dhaliwal, Salamon and Smith, 1982; Dhaliwal and Schepanski, 1984; Astami and Tower, 2006; Isa, 2014). Whichever incentives derive management decisions on accounting policies in Nigeria, company law requires audit committees to scrutinize their appropriateness before the financial statements are finalized and the oversight could only be effective with the independence of the committee.

\subsection{Audit Committee Independence and Accounting Policy Decisions}

According to the agency theory, managers would always try to achieve this purpose given their discretion in selecting accounting policies (Healy, 1995). Audit committees should be composed of competent members with the authority and the resources to secure shareholders' interests against managerial manipulations of accounting methods for personal gain (DeZoort et al., 2002). The code 2011 requires half of the committee's membership (three independent directors) to make the six-man committee independent. Audit committee independence is considered critical to its effective oversight functions (Poretti, Schatt and Bruynseels, 2018). Thus, a higher presence of outsiders in the committee increases its level of independence andthe ability to check the CEOs and prevent managerial opportunism. The results of Cacello and Neal (2000) support the idea that the audit committee should comprise entirely independent directors. Abbott, Parkand Parker(2002) found that audit committees composed of outsider directors are likely to safeguard the integrity of the financial reporting process.

Studies such as Cacello and Neal (2000) and Li, Lin and Yang (2006) found that audit committee independence was not significant in securing the interests of shareholders in the latitudes accounting process provided for managers. However, Abbott and Park (2000), Anderson, Mansi and Rebb (2004), Sharma and Chunli (2014), Soliman and Ragab (2014), Oliver and Grace (2017), Musa, Oloruntoba and Oba (2014), Ayemere and Elijah (2015),Chandrasegaram et al. (2013), Hamdan, Mushtaha and Al-Sartawi (2013), Salleh and Haat (2014), Wiralestari and Tanzil (2015), Kamolsakulchai (2015) and Habib and Bhuiyan, 2016) foundcontrary evidence. The evidence has been mixed across countries depending on the institutional enforcements of each country. In countries where there are stronger institutions, the functions of audit committees are enhanced and also their ability to fulfill their obligations becomes much easier (Cacello and Neal, 2003). Nigeria belongs to a group of LDC countries categorized with weak institutional enforcement.

\subsection{Audit Committee Monitoring and Financial Reporting Process}

Cacello and Neal (2003) found that an independent audit committee reduces the risk of corporate failure. Menon and Williams(1994) posed that most firms just comply with the legal requirement but not because they are performing their expected roles. In Nigeria, the audit committees monitoring performance could be considered as ineffective and the committee a mere legal compliance. For instance, Chukwunedu et al. (2015) showed that audit committees are faced with practical and legal constraints that have adversely affected their ability to adequately monitor the accounting process. Professional accounting bodies and the public are wary of the committees reports. The committee enjoys inadequate managerial backing with inconsequential faith, fewer responsibilities and unwilling respect (Atu, 2014).

Studies such as Bala (2014) and Isa and Farouk (2018) in Nigeria discovered that committees have been effective in their monitoring role, but much is left to be desired on their independence. To make the committee more independent and effective in monitoring, the drafted Nigeria Code of Corporate Governance (NCCG), which becomes effective by January 2020, proposed that the committee composed of only independent directors. Prior studies such asBowen DuCharme and Shores(1995), Astami and Tower (2006), Dey, Grinyer and Sinclair (2008), Jackson, Xiaotao and Cecchini (2009), Waweru, Ntui and Mangena(2011),Isa (2014) and Acaranupong (2017) in the literature of accounting choice did not examine the independence of the audit committee as a predictor of the 
accounting policy decisions of firms. This study tests the significance of audit committee independence on accounting policy decisions within this context to validate the proposition of the agency theory.

\section{Research Design}

Fifty-eight firms from the 114 non-financial firms listed on the NSE were studied from2012-2016. The data were extracted from the financial statements. A model similar to Bowen, DuCharme and Shores (1995) and Jackson, Xiaotao and Cecchini (2009) was modified and adapted to assess the predictors of the audit committee independence on firms' accounting policy decisions. The model specification is:

\section{$\mathrm{APC}=\beta 0+\beta 1$ AClit $+\beta 2 \mathrm{BCMit}+\beta 3 \mathrm{LEVit}+\beta 4$ FSZit $+\beta 5$ PRTit $+\beta 6$ LBRit $+\beta 7$ TAXit $+\beta 8$ STCit $+\beta 9$ SPLit $+\varepsilon$ it}

APCit is a dependent variable that represents the accounting policy decisions of firms. It is the ratio of the accounting policies of assets, which have the effects of increasing the reported income over the total assets accounting policies adopted and disclosed by the firms (Waweru, Ntui and Mangena, 2011). In this study, only the accounting policies on assets were considered because they provided widely used managerial discretion for accounting choice used in Nigeria. AClit is an explanatory variable that represents the audit independence committee. It is measured as the natural log of the numbers of the committee, who represent shareholders over the number of members, who represent directors (Isa and Farouk, 2018). There is growing evidence on the association of audit committee effectiveness and its oversight on the firm's accounting process (Parker, 1997; Abbott and Parker, 2000). This justifies the choice of the AClit as an explanatory variable on the accounting policy decisions of firms.

The explanatory variables in the model include the traditional predictors of accounting policy decisions of firms used by previous studies, such as Bowen, DuCharme and Shores (1995), Astami and Tower (2001), Jackson, Liu and Cecchini (2009), Waweru, Ntui and Mangena (2011) and Isa (2014). These include: FSZit that represents the size of the firm which is measured as the natural logarithm of the firm's total sales; LEVit represents the leverage of the firm and is measured as the ratio of the long-term borrowings to the shareholders' equity ( 0 if long-term borrowing is missing). And PRTit represents the profitability of the firm which is measured as the ratio of net income to adjusted total assets. BCMit represents board independence and is found significant in Waweru, Ntui and Mangena (2011) and Isa (2014).It is measured as the ratio of non-executive directors to the size of the board. The other category of traditional predictor variables for stakeholder expectations are based on party implicit claims: STCit represents creditors' expectations; it is measured as the ratio of short-term borrowings to equity; CGSit represents suppliers' expectations; it is measured as the natural logarithm of the cost of sales scaled by adjusted total assets. LBRit represents employee expectations; it is measured as one minus the ratio of gross PP and E to adjusted total assets (Bowen, DuCharme and Shores, 1995; Jackson, Xiaotao and Cecchini, 2009; Waweru, Ntui and Mangena, 2011; Ndjetcheu, 2012) and TAXit represent government expectations; it is measured as the natural logarithm of the accrued tax expenses scaled by adjusted total assets (Ndjetcheu, 2012).

\section{Results and Discussions}

\subsection{Descriptive Statistics}

The descriptive statistics are reported in Table 1. APCit, (accounting policy decision) has a mean of 0.74.This implies that the firms averagely choose income increasing policies. The mean of AClit is 2.74. This implies that the average outsiders in the committees are slightly below the required minimum. Further description of the composition of the audit committee's independence is reported in Table 2. The average value of the firms' size (FSZit) is $\$ 117.10$ with a standard deviation of $\$ 201.96$. These are accompanied by amaximum observation of $\$ 1,081$ billion and a minimum less than $\$ 0.07$ billion. These indicate greater variability among the firms because they are drawn from the various subsectors of the manufacturing sector.

Table 1: Descriptive Statistics

\begin{tabular}{|l|l|l|l|l|l|}
\hline & $\mathrm{N}$ & Mean & Stdev & Min & Max \\
\hline APC & 290 & 0.74 & 0.18 & .25 & 1.00 \\
\hline BCM & 290 & 0.66 & 0.17 & 0.00 & 1.00 \\
\hline FSZ (billion \$) & 290 & 117.10 & 201.96 & 0.07 & $1,081.15$ \\
\hline
\end{tabular}




\begin{tabular}{|l|l|l|l|l|l|}
\hline LEV & 290 & 0.27 & 0.51 & 0.00 & 5.17 \\
\hline PRT & 290 & 0.07 & 0.14 & -0.39 & 0.79 \\
\hline SPL (billion \$) & 290 & 81.00 & 134.00 & 0.12 & 621.00 \\
\hline LBR & 290 & 0.56 & 0.25 & 0.00 & 1.00 \\
\hline STC & 290 & 0.13 & 0.15 & 0.00 & 0.82 \\
\hline ACI & 290 & 2.74 & 0.51 & 1.00 & 5.00 \\
\hline TAX & 290 & 16.43 & 7.93 & 25.27 & 0.00 \\
\hline
\end{tabular}

This Table presents the description statistics of the study variables.

Table 2 presents the frequencies of the number of independent directors in the audit committee. The number of outsiders who represent shareholders in the committee among the firms ranges from 1 to 5 among the committees. It is revealed that about $26 \%$ of the audit committees had 2 outsiders. This is less than the benchmark of three outsiders prescribed by the code. However, about $72 \%$ of the committees had three outsiders as members which comply with the Code. Furthermore, it is discovered that only $1 \%$ and $0.4 \%$ of the audit committees had 4 and 5 outsiders respectively, which implies the highest level of independence. It could be stated that the majority of the audit committees enjoyed the purported amount of independence. These results imply significant compliance with the provisions of the Code.

Table 2: Frequency of Outsiders in Audit Committee

\begin{tabular}{|c|l|l|l|l|l|l|}
\hline Number of Outsiders & $2012 \%$ & $2013 \%$ & $2014 \%$ & $2015 \%$ & $2016 \%$ & Mean $(\%)$ \\
\hline 1 & 0.02 & 0.02 & 0.02 & 0.00 & 0.02 & 0.014 \\
\hline 2 & 0.26 & 0.25 & 0.26 & 0.26 & 0.25 & 0.256 \\
\hline 3 & 0.72 & 0.74 & 0.68 & 0.72 & 0.72 & 0.716 \\
\hline 4 & 0.00 & 0.00 & 0.02 & 0.02 & 0.02 & 0.010 \\
\hline 5 & 0.00 & 0.00 & 0.02 & 0.00 & 0.00 & 0.004 \\
\hline
\end{tabular}

This Table presents the frequencies of ACs outsiders, meetings and membership vis-à-vis the statutory benchmark.

\subsection{Accounting Policy Choice Decisions}

Table 3 presents the count of accounting policy decisions of the sampled firms on accounting policy on property, plant and equipment (PPE), goodwill (GDWL), software (SFTW), inventory (INVT), investment property (INVP) and depreciation methods (DEPM). From the results, the firms adopted the cost method (income increasing policy) $87 \%$ for PPE, $53 \%$ for GDWL, $94 \%$ for SFTW and 57\% for INVP of the decisions. All the decisions on the depreciation method by the firms favoured a straight-line method. Bowen,DuCharme and Shores (1995), Astami and Tower (2206) and Waweru, Ntui and Mangena (2011) classified the straight-line method as income increasing. It is discovered that $71 \%$ of the policy decisions on INVT was the average cost method. Bowen, DuCharme and Shores (1995) considered the straight-line method as an intermediate policy (between FIFO (income increasing) and LIFO (income decreasing). The results further indicate that the fair-value (income decreasing) method was not favoured by the policy decisions of the firms; they adopted only 5\% and 6\% of the decisions for PPE and SFTW, respectively. However, the policy was adopted for GDWL $47 \%$. 
Overall, it is discovered that an average of $69 \%$ of the firms' decisions favoured the income increasing policies, $29 \%$ of the decision adopted the income decreasing methods and $2 \%$ adopted mixed policies. This implies that firms predominantly used income increasing policies. This is consistent with the finding of Bowen,DuCharme and Shores (1995), Astami and Tower (2006), Waweru, Ntui and Mangena (2011) and Isa (2014).

Table 3: Accounting Policy Decisions of Firms

\begin{tabular}{|l|l|l|l|l|}
\hline & Disclosure & $\begin{array}{l}\text { Income } \\
\text { increasing }\end{array}$ & $\begin{array}{l}\text { Income } \\
\text { decreasing }\end{array}$ & Mixed \\
\hline Depreciation Method & 1.00 & 1.00 & 0.00 & 0.00 \\
\hline Property, Plant and Equipment & 1.00 & 0.87 & 0.05 & 0.08 \\
\hline Goodwill & 0.16 & 0.53 & 0.47 & 0.00 \\
\hline Intangible Assets Software & 0.64 & 0.94 & 0.06 & 0.00 \\
\hline Inventory & 1.00 & 0.23 & 0.71 & 0.06 \\
\hline Investment Property & 0.26 & 0.57 & 0.43 & 0.00 \\
\hline Mean & 0.68 & 0.69 & 0.29 & 0.02 \\
\hline
\end{tabular}

This Table presents the distribution of decision on accounting methods made by firms between 2012-2016.

\subsection{Analysis of the Regression Results}

Table 4 presents a summary of the regression results. The Adjusted R2 indicates that $24.83 \%$ of the changes in accounting policy decisions are explained by the variables composed in the model, which is higher than the moderate value of $19 \%$ suggested by Chin (1998). The F-ratio is 11.61 along with a p-value of 0.0000 . This indicates that the model is significant and good for estimating the incentives for accounting policy decisions of firms. Several tests were conducted to ensure that the assumptions of regression analysis were not violated. For instance, the constant variance assumption was tested using Breusch-Pagan and the null hypothesis was not support (chi-square $=1.80, \mathrm{p}$-value $=0.1792$ ) which indicates that heteroskedasticity is not a problem. Skewness/Kurtosis tests for the normality test was conducted and the results indicated that data were normally distributed (the joint chi-square $=2.92, \mathrm{p}$-value $=0.2327$. The variance inflation factor test showed a Mean VIF 1.69 (maximum of 2.60 for TAXit and minimum of 1.08 for BCMit). According to Craney and Surles (2002), no formal criteria exists for deciding if VIF is too large, but a value greater than 10 indicates a strong presence of multicollinearity that requires remedial measures. There were very few outliers outside the threshold of \pm 2 based on studentized residuals analysis which were not significant.

From the Table, it is discovered that ACIit, is not significant (t-statistics $=0.63$, p-value $=0.526$ ). This implies that the audit committee's independence level does not ensure effective incentive monitoring on the accounting policy decisions of the management. This result is inconsistent with the findings of Abbott and Park (2000) which states that firms with independent audit committees are more vigilant and ensure the objectivity and integrity of the accounting process. Contrary to Carcello and Neal's (2003) and Poretti, Schatt and Bruynseels' (2018) results, the findings did not validate the agency theory perspective that the presence of an independent audit committee would improve monitoring in favour of shareholders. However, consistent with previous studies (Waweru, Ntui and Mangena, 2011; Isa, 2014), the results indicated that an independent board (BCMit) is significant ( $\mathrm{z}$-values $=3.44$; p-values $=0.001)$ to the firms' accounting policy decisions. This implies that the central boards have taken over the responsibility of monitoring accounting process from the committees.

Stakeholder expectations are found to be significant predictors of the accounting policies decided upon by management. For instance, TAXit, $(\mathrm{z}$-values $=2.31 ; \mathrm{p}$-values $=0.022)$, CGSit, $(\mathrm{z}$-values $=5.56 ; \mathrm{p}$-values $=0.000)$ and STCit $(\mathrm{z}$-values $=4.52 ; \mathrm{p}$-values $=0.000)$ are significant to the decisions. This supports that firms recognize each stakeholder's expectations based on their implicit claims and merit consideration for its own sake in the accounting policy decisions (Donaldson and Preston, 1995), which is consistent with Bowen DuCharme and Shores (1995). The traditional predictors of accounting policy choice (Watts and Zimmerman, 1978) are found significant: PRTit, $(\mathrm{z}$-values $=1.67$; p-values $=0.097)$ and LEVit $(\mathrm{z}$-values $=1.84 ; \mathrm{p}$-values $=0.067)$ except the political costs hypothesis. This is contrary to the view of Ndjetcheu (2012). The bonus plan and the debt covenant hypotheses though significant are applicable in different contexts other than for managerial compensations and firms' risk 
control. These results imply that the managers' incentives to accounting policy decisions were derived by the quest to maximize shareholders' wealth, which could be aligned to managerial intentions to secure jobs and reputations.

Table 4: Regression Summary

\begin{tabular}{|l|l|l|l|l|}
\hline & Coefficient & Std. Error & t-value & Sig. \\
\hline Constant & 0.4676 & 0.1223 & 3.82 & 0.000 \\
\hline ACI & 0.0316 & 0.0498 & 0.63 & 0.526 \\
\hline BCM & -1.9543 & 0.5686 & -3.44 & 0.001 \\
\hline LEV & 0.1818 & 0.0988 & 1.84 & 0.067 \\
\hline FSZ & 4.4524 & 7.1484 & 0.62 & 0.534 \\
\hline PRT & -0.1518 & 0.0912 & -1.67 & 0.097 \\
\hline LBR & -0.0311 & 0.0242 & -1.28 & 0.201 \\
\hline TAX & 0.0042 & 0.0018 & 2.31 & 0.022 \\
\hline STC & -0.3316 & 0.0734 & -4.52 & 0.000 \\
\hline SPL & 0.0121 & 0.0022 & 5.56 & 0.000 \\
\hline Adjusted R2 & & & 0.2483 & \multicolumn{2}{|l|}{} \\
\hline F-value & & & 11.61 & 0.0000 \\
\hline P-value & & & \multicolumn{2}{|l|}{} \\
\hline
\end{tabular}

\section{Conclusions}

The study examined the impact of audit committee independence on accounting policy decisions by linking the monitoring incentives on the efficiency of the management choice of accounting policy. Fifty-eight listed firms in Nigeria were studied for 290 accounting years. Data were collected from the available financial reports of the firms and analysed using a model similar to Bowen DuCharme and Shores (1995) and Jackson, Xiaotao and Cecchini (2009). The results showed that the firms predominantly used income increasing accounting policies, which include cost model and straight-line depreciation method, which implies income increasing strategy. It also discovered that a significant number of the audit committees have met up the required number of independent directors as prescribed by the 2011 code of corporate governance, which is meant to strengthen their independence for effective monitoring. However, this did not ensure effective monitoring of the accounting policies selections. Boards monitoring suppressed that of the audit committees because either the committees are not given the required authority or they have been passive. This implies that the interests of management and those of the shareholders in the selection of the accounting policies are aligned. This brings the oversight of the committees to the limelight once again. Thus, the firms setup the audit committees not because they wanted to rely on them for effective monitoring but to fulfil the statutory requirement of CAMA 2014 as amended. This conclusion is consistent with the view of Menon and Williams (1994). This discovery is contrary to the views of Fields, Lys and Vincent (2001) and Ndjetcheu (2012): audit process does not ensure effective monitoring on accounting policy decisions. This evidence extends the literature of accounting choice in relation to the role of audit process.

These findings have implications for FRCN to reinforce the committees to be effective in monitoring. Although the new code, which becomes effective January 2020, requires the committee to be composed mainly of independent directors, they would need the required authority to undertake their oversight functions. Members of the committee should be required to engage in periodic capacity development and self-assessment for quality control for responsible engagement in their monitoring functions. The study makes a major contribution to the accounting policy choice literature, as it relates to audit committee independence. Further studies can focus on evaluating the authority of the committee and the financial literacy of members in Nigeria.

\section{References}

Abbott, L. J., \& Park, Y. (2000). The Effects of Audit Committee Activity and Independence on Corporate Frau. Managerial Finance, 26 (11), 55-67.

Abbott, L. J., Park, Y., \& Parker, S. (2002). The efects of audit committee activity and independence on corporate fraud. Managerial Finance,26(11), 55-67.

Acaranupong, K. (2017). Accounting practices and value relevance of investment property: evidence from firms 
listed on the stock exchange of Thailand. Asian Journal of Business and Accounting, 10 (2), 1-41.

Anderson, R. C., Mansi, S. A., \& Rebb, D. M. (2004). Board characteristics, accounting Report integrity, and the cost of debt. Journal of Accounting and Economics, 37, 315-342.

Astami, E. W., \& Tower, G. (2006). Accounting-policy choice and firm characteristics in the Asia Pacific region: An international empirical test of Costly Contracting Theory. The International Journal of Accounting, 41, $1-21$.

Atu, O. O. K. (2014). Audit committees: the journey so far in Nigeria.IOSR Journal of Economics and Finance, 3(1), 40-43.

Ayemere, I. L., \& Elijah, A. (2015)Audit committee attributes and earnings management: evidence from Nigeria. International Journal of Business and Social Research, 5(4), 14-23.

Bala, H. (2014). Audit committee characteristics and earnings management of listed food and beverages firms in Nigeria (Unpublished mater's thesis). Ahmadu Bello University, Zaria, Nigeria.

Bagnoli, M. \& Watts, S. G. (2005). Conservative accounting choices. Management Science, 51(5) 786-801.

Bealing, B. R., Nelson, D. W., \& Staley, A. B. (2006). An institutional perspective of the Sarbanes-Oxley-Act. Managerial Auditing Journal, 21, 23-33.

Beneish, M. D. (2001). Earnings Management: A perspective. Managerial Finance 27(12), 3-17.

Bowen, R. M., DuCharme, L., \& Shores, D. (1995). Stakeholders' implicit claims and accounting method choice. Journal of Accounting and Economics, 20, 255-295.

CAMA (2004). Companies and Allied Matters Act 2004 as amended. Federal Government of Nigeria, Abuja.

Cairns, D., Massoudi, D., Taplin, R. \& Tarca, A. (2011). IFRS fair value measurement and accounting policy choice in the United Kingdom and Australia. The British Accounting Review, 43 (1), 1-21.

Carcello, J. V. \& Neal, T. L. (2000). Audit committee composition and auditor reporting. The Accounting Review, 75(4), 453-467.

Carcello, J.V.\& Neal, T.L.(2003). Audit committee characteristics and auditor dismissals following new goingconcern audit reports. The Accounting Review, 78, 95-117.

Chandrasegaram, R., Rahimansa, M. R., Rahman, S. K. A., Abdullah, S., \& Nik Mat, N. (2013). Impact of audit committee characteristics on earnings management in Malaysian public listed companies. International Journal of Finance and Accounting, 2(2), 114-119.

Chukwunedu, O.S., Ogochukwu, O.G., Egbunike Francis Chiedu, E.F. (2015). Audit committee effectiveness in nigeria: the perception of professional accountants. International Journal of Management Sciences, 5(2), 125-135.

Craney, T. A. \& Surles, J. G. (2002). Model-Dependent variance inflation factor cutoff values. Quality Engineering, 14(3) 391-403, DOI: 10.1081/QEN-120001878

Dey, C. R., Grinyer, J. R., \& Sinclair, C. D. (2008). Deerminants of accounting choices in Egypt. Journal of Applied Accounting Research, 8(3), 48-92.

DeZoort, F. T., Hermanson, D. R., Archambealt, D. S., \& Reed, S. A. (2002). Audit committee effectiveness: a synthesis of the empirical audit committee literature. Journal of Accounting Literature, 21, 38-75.

Dhaliwal, D. S., \& Schepanski, A. A. (1984). On the issue of positive economic theory to explain the choice of accounting methods to financial accounting students. Journal of Accounring Education, 2(2), 91-96.

Dhaliwal, D. S., Salamon, G. L., \& Smith, D. E. (1982). The effect of owners versus management control on the choice of accounting methods. Journal of Accounting and Economics, 4, 41-53.

Donaldson, T. and Preston, L. E. (1995). The stakeholder theory of the corporation: concepts, evidence, and implications. The Academy of Management Review, 20 (1) 65-91.

Fields, T. D., Lys, T. Z., \& Vincent, L. (2001). Empirical research on accounting choice. Journal of Accounting and Economics, 31, 255-307.

Fitchtner, J. R. (2010). The recent international growth of mandatory audit committee requirements. International journal of disclosure and governance,7(3), 227-243.

Francis, J. (2001). Discussions of empirical research on accounting choice. Journal of Accounting and Economics,31, 303-319. 
Habib, A., \& Bhuiyan, M.U. (2016). Problem directors on the audit committee and financial reporting quality. Journal of Accounting and Business Research, 46(2), 121-144.

Hamdan, A. M. M., Mushtaha, S. M. S., \& Al-Sartawi, A. M. (2013). The audit committee characteristics and earnings quality: Evidence from Jordan. Australasian Accounting, Business and Finance Journal, 7(4), 5180.

Healy, P. M. (1985). The effect of bonus schemes on accounting decisions. Journal of Accounting and Economics, 7, 85-107

Healy P. M. \& Wahlen, J. M. (1999). A review of the earnings management literature and its implications for standard setting. Accounting horizon, 13(4), 365-383.

Holthausen, R.W. (1990). Accounting method choice: opportunistic behavior, efficient contracting and information perspectives. Journal of Accounting and Economics, 12 (1-3), 207-218.

Isa, M. A. (2014). Determinants of of accounting choice of noncurrent assets at IFRS first adoption among Nigerian firms. Procedia - Social and behavioral Sciences, 164, 378-383.

Isa, M.A. \& Farouk, M.A. (2018). A Study of the effect of diversity in the board and the audit committee composition on earnings management for low and high leveraged banks in Nigeria. Journal of Accounting, Finance and Auditing Studies, 4(1), 14-39.

Jackson, S. B., Xiaotao, L. K., \& Cecchini, M. (2009). Economic consequences of firms' depreciation method choice: Evidence from capital investments. Journal of Accounting and Economics,48, 54-68.

Kamolsakulchai, M. (2015). The impact of the audit committee effectiveness and audit quality on financial reporting quality of listed company in stocks exchange of Thailand. Review of Integrative Business and Economic Research, 4(2), 328-341.

Klein, A. (2002). Economic determinants of audit committee independence. The Accounting Review, 77 (2), $435-$ 452.

Lin, J. W., Li, J. F., \& Yang, J. S. (2006). The effect of audit committee performance on earnings quality. Managerial Auditing Journal, 21 (9), 921-933.

Menon K. , \& Williams, J. D. (1994). The use of audt committee for monitoring. Journal of Accounting and Public Policy, 13, 121-139.

Moses, T. (2016). Audit committee number of meetings and earnings management in quoted Nigerian banks. International Journal of Advanced Academic Research,2(6), 14-23.

Musa, F. I., Oloruntoba, F. O., \& Oba, V. C. (2014). Examination of the relationship between audit committee characteristics and financial reporting quality of Nigerian Deposit Banks. Journal of Banking, Finance and Accounting,33(1), 1-15.

Naciri, A. (2008). Corporate governance around the world, Routledge, New York, NY.

Ndjetcheu, L. (2012). An African critical interpretation of the positive theory of accounting of Watts and Zimmerman (1978, 1980, 1986). African Journal of Accounting, Auditing and Finance,1(1), 25-39.

Oliver, O., \& Grace, N. O. (2017). Effect of audit committee qualities on financial reporting of listed companies in Nigeria: A perspective study. International Journal of Scientific and Research Publications,7(10), 278-290.

Parker, S. (1997). The effect of audit committees on financial reporting, Unpublished thesis. University of Oregon.

Poretti, C., Schatt, A. \& Bruynseels, L. (2018). Audit committees' independence and the information content of earnings announcements in Western Europe. Journal of Accounting Literature, 40, 29-53.

Salleh, N. M. Z., \& Haat, M. H. C. (2014). Audit committee and earnings management: pre and post MCCG. International Review of Management and Business Research, 3(1), 307-318.

SEC (2011). Code of corporate governance. Securities and Exchange Commission, Abuja, Nigeria.

Sharma, V. D., \& Chunli, K. (2014). Voluntary audit characteristics, incentives, and aggressive earnings management: Evidence from New Zealand. The International Journal of Auditing,18(1), 76-89.

Soliman, M. M., \& Ragab, A. A. (2014). Audit committee effectiveness, audit quality and earnings management: An empirical study of the listed companies in Egypt. Research Journal of Finance and Accounting,5(2), 155-166. 
Warfield, T. D., Wild, J. J. \& Wild, K. L. (1995). Managerial ownership, accounting choices, and informativeness of earnings.Journal of Accounting and Economics 20, 61-91.

Watts, R. L., \& Zimmerman, J. L. (1978). Towards a positive theory of the determination of accounting standards. Accounting Review,53, 112-134.

Watts, R. L., \& Zimmerman, J. L. (1990). Positive accounting theory: a ten year perspective. The Accounting Review,65(1), 131-156.

Waweru, N. M., Ntui, P. P., \& Mangena, M. (2011). Determinants of different accounting methods choice in Tanzania A positive accounting theory approach. Journal of Accounting in Emerging Economies, 1(2), 144159.

Wiralestari, Tanzil, N.D. (2015). The effectiveness of audit committee toward financial reporting's quality (nonfinancial issuers listed in Indonesia Stock Exchange). Research Journal of Finance and Accounting, 6(10), 186-189.

Zmijewski, M. E., \& Hagerman, R. L. (1981). An income strategy approach to the positive theory of accounting standard setting/choice. Journal of Accounting and Economics,3, 129-149. 


\section{APPENDIX}

- regress apc nlogaci bcms levs szes roa lbr tax stc cgs

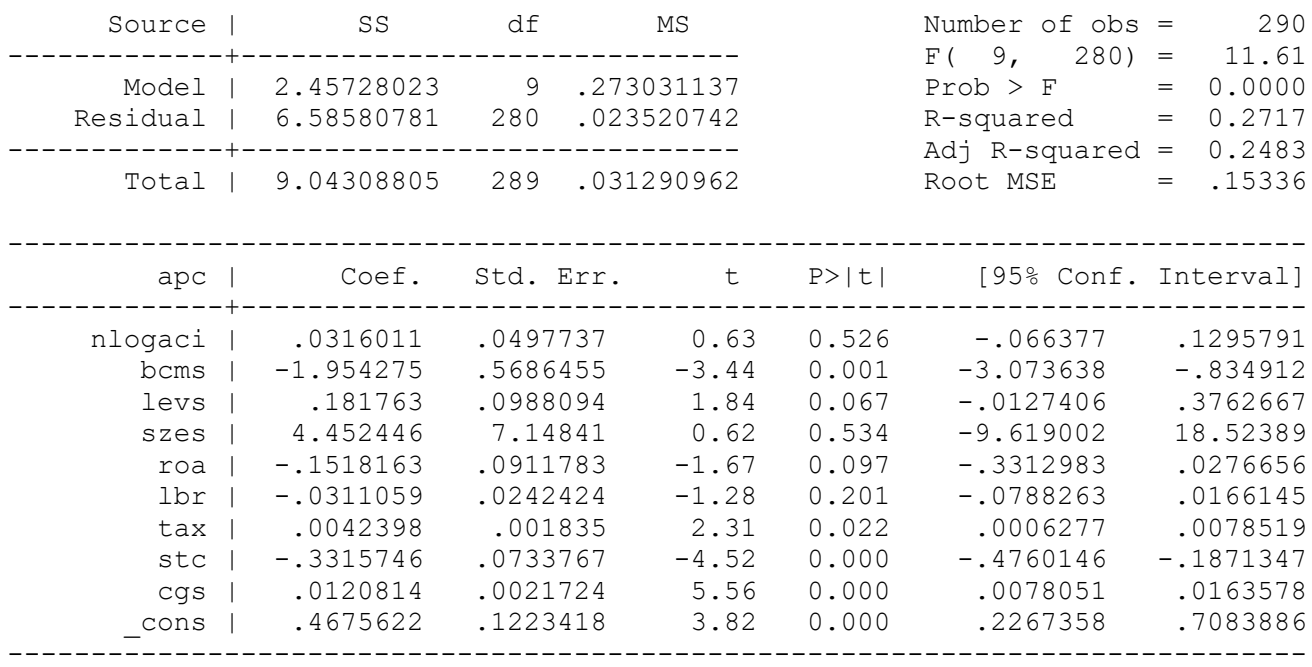

- predict myres, resid

- sktest myres

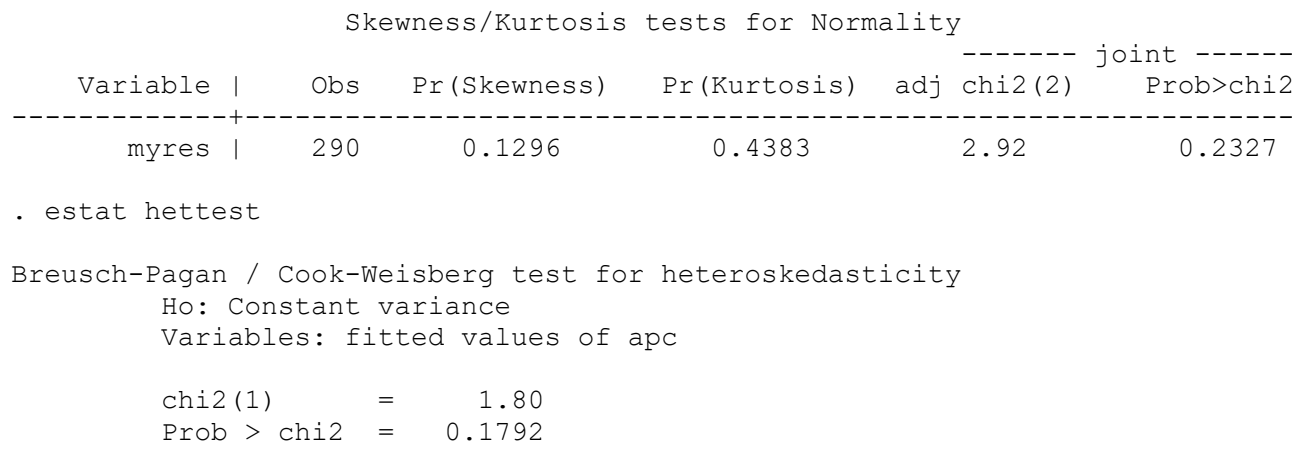

- pwcorr nlogaci bcms levs szes roa lbr tax stc cgs, sig

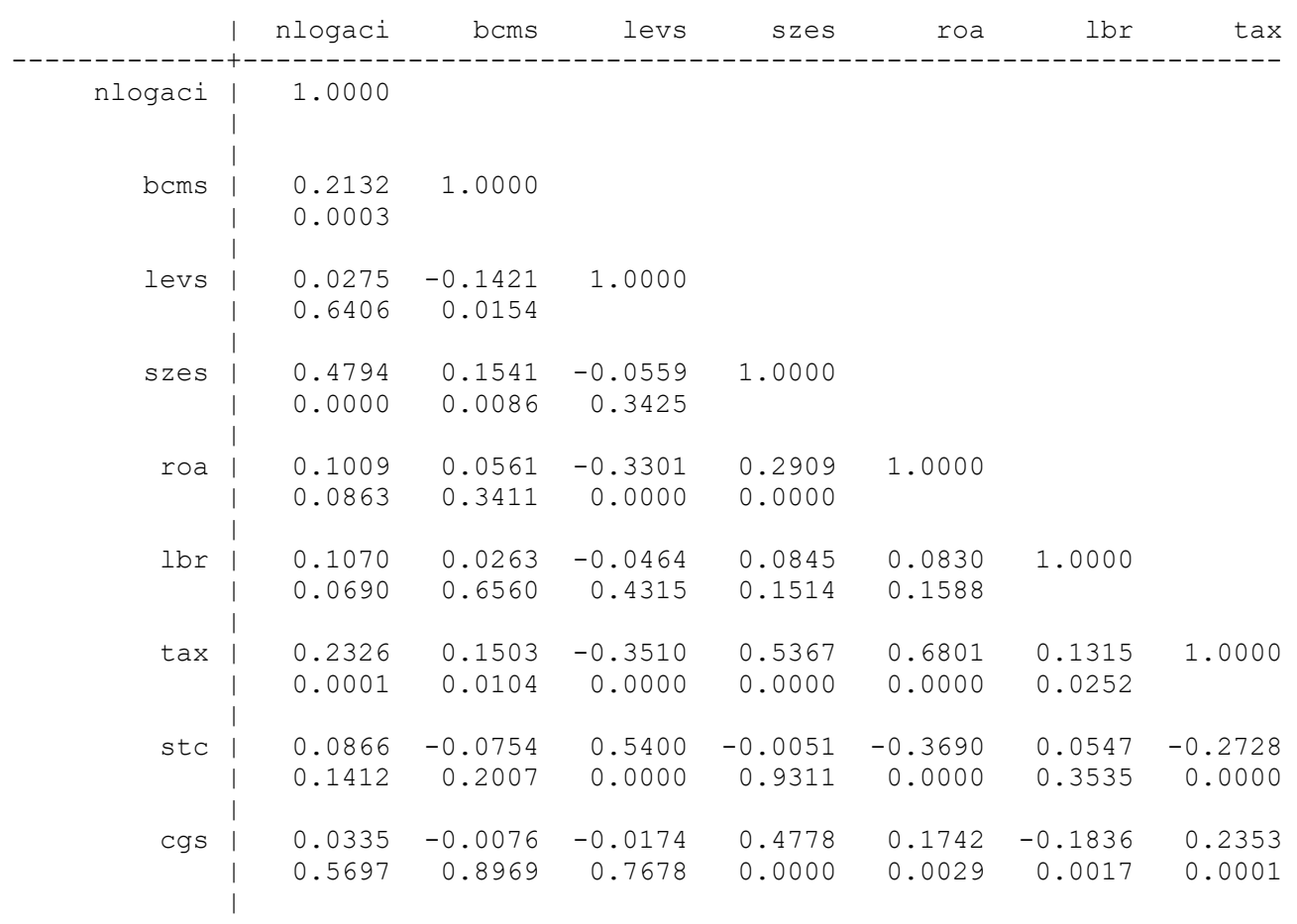




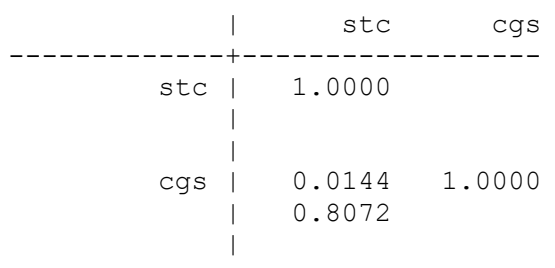

\begin{tabular}{|c|c|c|}
\hline Variable & VIF & $1 / \mathrm{VIF}$ \\
\hline tax & 2.60 & 0.384496 \\
\hline szes & 2.34 & 0.426738 \\
\hline roa & 2.03 & 0.491612 \\
\hline stc & 1.55 & 0.644519 \\
\hline levs & 1.54 & 0.648056 \\
\hline $\mathrm{cgs}$ & 1.50 & 0.668534 \\
\hline nlogaci & 1.44 & 0.694560 \\
\hline lbr & 1.11 & 0.904941 \\
\hline $\mathrm{bcms}$ & 1.08 & 0.922585 \\
\hline
\end{tabular}

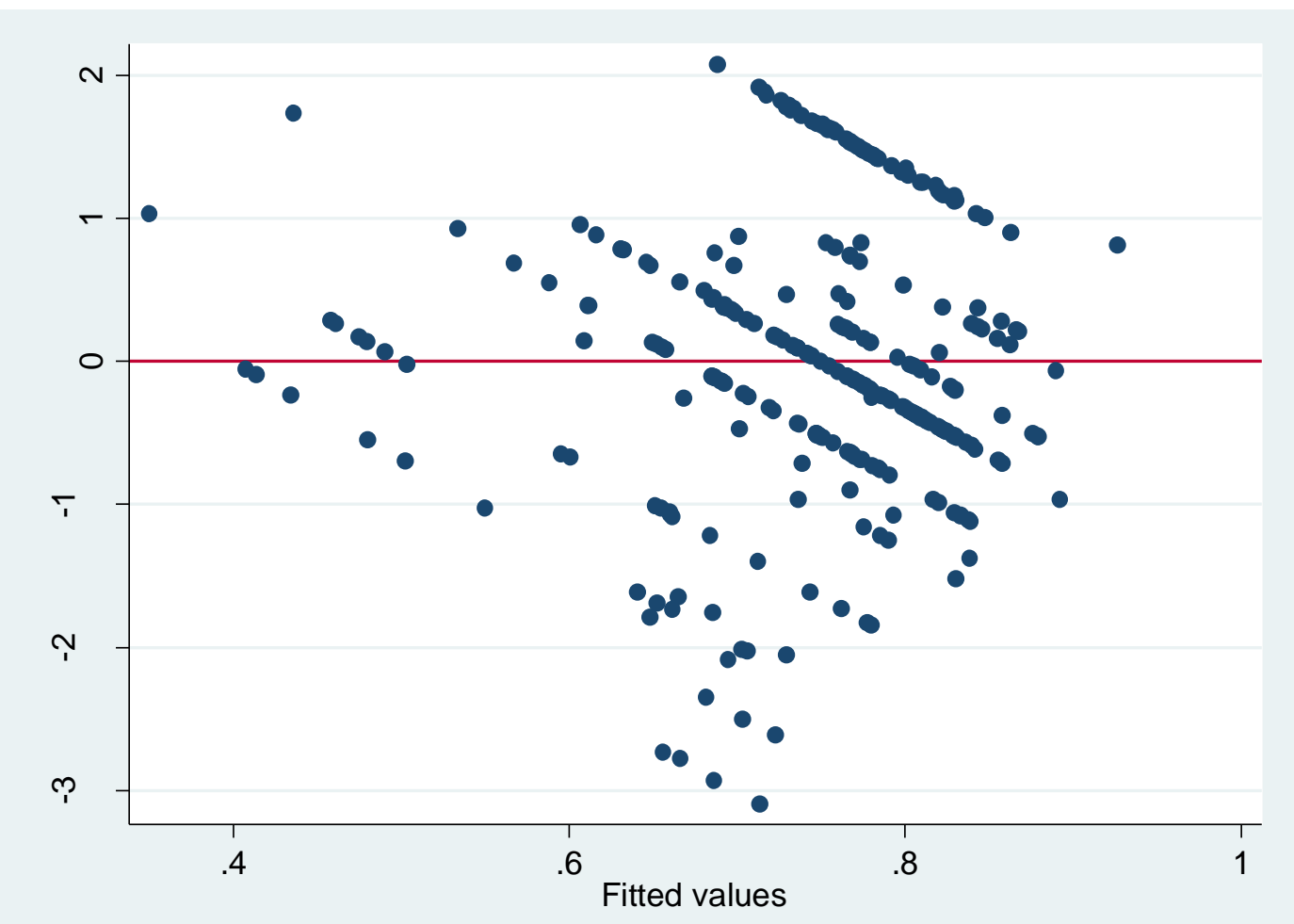

